\title{
CLASSROOM INTERVENTION: READING TONI MORRISON'S A MERCY WITHIN INDONESIAN CONTEXT
}

\author{
Lestari Manggong \\ Universitas Padjadjaran \\ Email: lestari.manggong@ unpad.ac.id \\ D OI: http:/ / dx.doi.org/ 10.17509/ bs jpbsp.v17i2.9657
}

\begin{abstract}
Since knowledge often suits a situation, knowledge can work as a strategy. Spivak (1993) emphasizes that classroom can be staged as intervention. In the classroom, a case, a theory, or a concept is proposed, and students are encouraged to intervene. In Spivak's "teaching machine", it is strategic to always move outside and not be like the mainstream. To do this, one must inhabit, invest, and criticize the knowledge put in hand. With this in mind, this essay attempts to explore how reading literature can help Indonesians negotiate their identities across languages, generations, and cultures, and in the end, would look critically at the politics of identity and culture. This article argues that reading Toni Morrison's A Mery provides perspectives on the relevance of teaching American literature within Indonesian context. Tzvetan Todorov's (1982) theory on the conquest of other helps the analysis on the novel's colonial issue, while the conquest of America by female characters in the novel is discussed within the frame of feminist studies. Intervention in this case is conducted to question what can be reflected upon such issues for students in Indonesia whose country experienced (post)colonialism and is continuously tackling with the issue of gender equality.
\end{abstract}

Keywords: American literature; feminist studies; Indonesian context; intervention; (post)colonialism.

\section{INTERVENSI KELAS: MEMBACA NOVEL A ME RCY KARYA TONI MORRISON DALAM KONTEKS IN DONESIA}

\begin{abstract}
Abstrak
Karena pengetahuan sering sesuai dengan situasi, pengetahuan dapat digunakan sebagai strategi. Spivak (1993) menekankan bahwa ruang kelas dapat dikondisikan sebagai medium intervensi. Di ruang kelas, sebuah kasus, teori, atau konsep diajukan, dan siswa didorong untuk melakukan intervensi. D alam konteks mesin pengajaran yang dikonsepkan oleh Spivak, selalu bergerak keluar (tidak mainstream) merupakan hal yang sangat strategis untuk dilakukan. Untuk dapat melakukan ini, seseorang harus benar-benar memahami, menginvestasikan, dan mengkritik pengetahuan yang ada. Atas dasar pemikiran ini, artikel ini mencoba untuk mengeksplorasi bagaimana membaca karya sastra dapat membantu orang Indonesia menegosiasikan identitas mereka melalui bahasa, generasi, dan budaya. Hingga pada akhirnya, akan terlihat kritik terhadap politik identitas dan budaya. Artikel ini berargumentasi bahwa membaca novel A Mecykarya Toni Morrison dapat memberikan perspektif tentang relevansi pengajaran sastra Amerika dalam konteks Indonesia. Teori Tzvetan Todorov (1982) tentang penaklukan yang lain membantu analisis isu kolonial novel tersebut, sementara penaklukan Amerika oleh tokoh perempuan dalam novel tersebut akan dibahas dalam kerangka studi feminis. Intervensi dalam kasus ini dilakukan untuk mempertanyakan apa yang dapat tercermin pada isu-isu tersebut bagi siswa di Indonesia yang negaranya mengalami kolonialisme dan terus-menerus menangani masalah kesetaraan jender.
\end{abstract}

Kata kunci: kesusastraan Amerika; kajian feminis; konteks Indonesia; intervensi; (pos)kolonialisme 


\section{INTRODUCTION}

Knowledge can work as a strategy, since knowledge often suits a situation. In the teaching machine (Spivak, 1993), it is strategic to always move outside. To do this, one must inhabit, invest, and criticise the knowledge put in hand. Since classroom can be staged as intervention, and if what is being intervened, for instance, is Toni Morrison's A Mery, one can explore critically the politics of identity and culture relevant to Indonesian students who are individuals negotiating their identities across languages, generations, and cultures. As far as this essay is concerned, the discussion in this essay attempts to explore how reading literature can help Indonesians negotiate their identities across languages, generations, and cultures, and in the end, would look critically at the politics of identity and culture.This essay argues that reading Toni Morrison's A Mery, provides perspectives on the relevance of teaching American literature within Indonesian context. Tzvetan Todorov's (1982) theory on the conquest of other helps the analysis on the novel's colonial issue, while the conquest of America by female characters in the novel will be discussed within the frame of feminist studies. Intervention in this case is conducted to question what can be reflected upon such issues for students in Indonesia whose country experienced (post)colonialism and is continuously tackling with the issue of gender equality.

\section{METHOD}

The discussion of this essay relies greatly on Spivak's concept. Spivak learns that her position is '[o]utside in every machine', even for the Subaltern Studies Group. As one of the subalternists, Spivak also learns 'to ask questions [she] hadn't thought of [her]self.' (Spivak, 1993: 23) Her point here redefines the significance of being an anti essentialist, which is one of the main issues asked in her interview regarding where she places herself as an anti essentialist. In reading A Mery, Indonesians are outside the line of American history, but they are inside the line of world history, more specifically the history of colonialism. This matter will be tackled with Todorov's (1983) study of the complex relationship between "I" and "Other," which further provides a general view on how the relationship between the coloniser and the colonised works.

Since the practice of colonialism has to do with the history of world's finance, particularly with attempts to enrich the colonizing country to fund wars against their opposing countries (Ferguson, 2009), the practice of slavery and any form of repression towards inferior race was made legal by law. It is all, in the words of Conrad's (1899), for the sake of 'efficiency'. The era where the story is set is a century after European settlements in America, which was when Southern colonies were strongholds of slavery. Within this time setting, the novel-Morrison claimed in interviews and a speech-is intended to provide a description '[w]hen slavery had not yet been coupled with race, ${ }^{11}$ an attempt to 'separate racism from slavery," because to her, '[w]e seem in this country to combine the idea of slavery and race, but that isn't true. ${ }^{3}$ Minha mãe $\square$ s story in the last chapter redefines the notion that human trading is an act done by the white settlers. It is in fact also an act done by black Africans. To tackle with the issue, this essay discusses the juxtaposition of fate and circumstance within the concept of "antimiraculation" (Spivak, 1993), critiques the idea of slave by choice and the inability to seek a way out of the state of being someone else $\square$ s ownership, and pinpoints an act of preserving existence in a form of history.

\section{FIN DIN GS AN D DISCUSSION A Fom of Antimiraculation}

Florens, an American-born slave, is the main narrator of the story that tells about her days as a slave in 1690, which was a period when America experienced foetal phase of diversity and complexity of human races compared to what is generally imagined today. In the history of America, late seventeenth century marks the pivotal years of the practice of slavery since the first 


\section{P0J urral PerddkanBaresacknSestra. V dume17, Nomor 2, Oktdber 2017, hlm 188-195}

African slaves were brought to the North American colony of Jamestown, Virginia, in 1619 , to aid in the production of tobacco. ${ }^{4}$

As a slave, Florens is seen as a commodity, not flesh and blood. Slaves, in the late seventeenth century were seen as 'pieces of eight', a term that means Spanish silver coins. In the novel, minha mãe ${ }^{5}$, Florens' mother, notices that Vaark (a Dutch plantation owner) does not see her daughter as such. Florens' fate changes by an act that is human, an act of mercy, from Vaark, to pay the debt of minha mãe's master, D'Ortega (a Portuguese plantation owner), as described in the following:

'Take you, my daughter. Because I saw the tall man see you as a human child, not pieces of eight. I knelt before him. Hoping for a miracle. He said yes.

It was not a miracle. Bestowed by God. It was a mercy. Offered by a human'

(Morrison, 2009: 195).

The title of the novel, which has its reference from this citation, raises critical questions that what happens in the series of history does not necessarily involve divine intervention such as miracle '[b]estowed by God' but more of something human, a mercy. This is controversially enlightening, in a sense that the reader is reminded that history rolls under the control of men, not necessarily God.

Spivak (1993,p.11) once came up with a term "antimiraculation" 6 upon raising the mysterious side of the word experience that to her is similar 'as the mother tongue,' which is 'something one is inserted in.'Antimiraculation, in the citation, works in a way that the change of fate experienced by Florens is simply another situation to where 'one is inserted in.' In other words, Florens is conditioned to have such a change of fate. 'That experience,' to Spivak, 'makes the strongest bond and also produces the greatest impatience with antiessentialism as a battle cry.' (1993,p. 11) And this is the condition that enables one to constantly question what they see on the inside from the outside. In the same interview, Spivak shares the fact that she is a middle-class child in the part of India where she attended neither 'a more fashionable "Western" school or a less fashionable "native" school.' She attended a school whose teachers decided to become Christians, thus castewise is seen lower, even outcastes. Her childhood experience makes her what she is. It enables her to see multiple sides of the story and raises questions on the complexities they create.

This form of "antimiraculation" in the novel can be seen as criticising fate and circumstance by juxtaposing the two. Lina-another slave in the Vaarks' household who is a Native American-believes that it is the world that shapes us. Florens is under the impression that the blacksmith is her shaper and her world. As slaves, born and bred, they have noknowledge of how life on the other side of the fence is like. This hinders them to see themselves from the outside. If minhamãe is said to have miraculously survived the journey to Barbados where she is traded, Florens' survival from the wicked hands of the D'Ortega is purely to do with minhamãe's perceptiveness on the way Jacob Vaark looks at Florens.

\section{A Slave by Choice}

Florens is given a path to lead another phase of her slave story, and along her journey, the reader is provided with the history and present circumstances of each of the characters through their narrative voice. We learn, for instance, about Jacob Vaark's history in Chapter Two where he is told to have set foot in 1682 Virginia. We also learn that he is a disowned child of a Dutch father who comes to America as an agent of The Dutch West India Company trading fur and lumber, but later turns to farming (and, later, tries his luck with the rum trade) after he inherits some land from an uncle. $\mathrm{He}$ prefers female labours than male, 'based on his own experiences as a youth. A frequently absent master was invitation and temptation- to escape, rape or rob' (Morrison, 2009,p. 39). In his household, 
lives Lina and Sorrow of Native American and mixed race origins, who are the two other slaves aside from Florens. There are also two white male servants, Willard and Scully. Jacob's daughter, the Mistress, as the slaves and servants call her, is Rebekka, who grows attached to Lina.

In Jacob's household, Florens experiences things she has not experienced before, something as simple as a man raising his hat when he walks past her.

'A boy and a dog drive goats past us. He raises his hat. That is the first time any male does it to me. I like it. A good sign I am thinking but Lina is warning me of many things, saying if you are not in your place I must not tarry. (Morrison: 44)

But Lina $\square$ s warning suggests Florens to realise who she is and where she is now. They take themselves as slaves and they are told to accept that. Florensinternalises her being a slave, someone else $\square$ s property, to the point where she does not feel comfortable of tasting a hint of freedom, as described in the following: 'I am a little scare of this looseness. Is that how free feels? I don't like it. I don't want to be free of you because I am live only with you (Morrison: 82). Here, Florens' expression is addressed to the unnamed blacksmith, a character who helps around Jacob's household and to whom Florens develops an obsession to. What Lina tells Florens afterwards again indicates passiveness: 'We never shape the world she says. The world shapes us,' to which Florens responses: 'I am not understanding Lina. You [the blacksmith] are my shaper and my world as well. It is done. No need to choose' (Morrison: 83).

Another part that elaborates a critical view on the way Florens sees herself as a slave is pointed out in the following:

'Why are you killing me I ask you.

I want you to go.

Let me explain.

No. Now.

Why? Why?
Because you are a slave.

What?

Y ou heard me.

Sir makes me that.

I don't mean him.

Then who?

You.

What is your meaning?

I am a slave because Sir trades for me.

No. You have become one.

How?

Your head is empty and your body is wild.

I am adoring you.

And a slave to that too.

You alone own me.

O wn yourself, woman, and leave us be. You

could have killed this child.

No. Wait. Y ou put me in misery.

You are nothing but wilderness. No constraint. No mind.

You shout the word-mind, mind, mind- over and over then you laugh, saying as I live and breathe, a slave by choice.' (Morrison: 166-7)

This is the part when Florens expresses her adoration to the blacksmith, which is also the part where the blacksmith helps Florensrealise that without her knowing it, she has become a slave not because her master trades for her, but because she chooses to be one. From what the blacksmith says, because she cannot own herself, it is clear that Florens cannot seek her way out of the state of being someone else's ownership. As 'nothing but wilderness. No constraint. No mind,'Florens is untamed, limitless, and unknowledgable, which is everything the white people are not. Here the reader is put an example of that classic gap between the civilised and uncivilised, master and slave, and coloniser and colonised. Todorov's study of the complex relationship between "I" and "O ther" provides a general view on how the relationship between the coloniser and the colonised works.

Todorov (1983) argues that fundamentally what puts "I" and the other individual who is also an "I" (because 'dhes are also " $I$ " s') on different sides of the road is point of view. In the point of view of the "I", the other "I" seems like another 


\section{P2J urral PerddkanBałasacenSestra V dume17, Nomor 2, Oktdber 2017, hlm 188-195}

individual. Because this other "I" becomes not part of the "I", then this other "I" looks more like an abstraction, 'an instance of any individual's psychic configuration,' as the Other. Because this other individual/ abstraction is an Other, it then is foreign. Because it is foreign, "I" find it hard to identify itself with it. Todorov continues by saying

\begin{abstract}
'[t]his group [of Other] in turn can be interior to society; women for men, the rich for the poor, the mad for the "normal"; or it can be exterior to society, i.e., another society which will be near or far away, depending on the case: beings whom everything links to me on the cultural, moral, historical plane; or else unknown quantities, outsiders whose language and customs I do not understand, so foreign that in extreme instances I am reluctant to admit they belong to the same species as my own' (Todorov, 1984, p. 3).
\end{abstract}

The natives of the New World, in Columbus' point of view, is foreign, another individual. Visually, they do not share the same standard of propriety as the Europeans; they do notproperly clothe. Other than that, they cannot communicate properly (proper according to Columbus' standard). Since Columbus-as expressed by Todorov- 'does not identify himself,' the act that occured is conquest, that leads to repression. Columbus' initial motive was to explore, crossing the Atlantic ocean, in the quest for Asia. He then discovered the New World. Since this was his motive, the exploration was not based on the intention to learn and adapt with the natives in this new land. What happens next is that Columbus imposed the values he believed in towards the natives. (Todorov, p.185-186) The era when the novel is set is the aftermath of the voyages of conquest, and the conquest agenda has magically morphed into an agenda of colonization' (Harris, 2010,p. 4).

What is intriguing in this novel is that there is no indication that Jacob, Rebekka, and the blacksmith (all three of the white characters) are imposing their values to Florens, Lina, or Sorrow. The blacksmith's remark on the citation entails disappointment, and this is not something that is normally seen in fictions that deal with colonial issue or slavery. This can potentially make the reader rethinks on putting the blame on the white people, because what this novel insinuates is that it blurrs the complex boundaries between race and gender. Race does not seem to be Jacob's main consideration in terms of purchasing a slave. His main consideration is that based on his experience, it is less risky to choose female labours rather than male.

\section{Women in the Wildemess}

After Jacob dies and when Rebekka falls ill, the fate of Florens, Lina and Sorrow is in jeopardy because '[f]emale and illegal, they would be interlopers, squatters, if they stayed on after Mistress died, subject to purchase, hire, assault, abduction, exile.' (Morrison: 68). Together, the three bond sisterhood and look after one another. Scully has an observant perception on Lina. Lina's loyalty, Scully believes, is not 'submission to Mistress or Florens; it was a sign of her own self-worth-a sort of keeping one's word. Honor, perhaps' (Morrison: 178). In revealing Rebekka's close attachment to Lina and Rebekka's fate in the search of a husband, the narrator's voice takes Rebekka's side and speaks out an idea that nothing is unbearable in the wilderness of America.

'Hence marriage to an unknown husband in a far-off land had distinct advantages: separation from a mother who had barely escaped the ducking pond; from male siblings who worked days and nights with her father and learned from him their dismissive attitude toward the sister who had helped rear them; but especially escape 
from the leers and rude hands of any man, drunken or sober, she might walk by. America. Whatever the danger, how could it possibly be worse?' (Morrison: 91)

Florens' journey to fetch the blacksmith to aid Rebekka is the very representation of making it to the other end of obstacle course and accomplishing her mission.

After three months apart from the blacksmith, Florens lays down her confession in a letter:

'I am holding light in one hand and carving letters with the other. My arms ache but I have need to tell you this. I cannot tell it to anyone but you. I am near the door and at the closing now. What will I do with my nights when the telling stops? D reaming will not come again. Sudden I am remembering. Y ou won't read my telling. You read the world but not the letters of talk. You don't know how to. Maybe one day you will learn' (Morrison: 188).

Her confession permeates in every other chapters in the novel, written from Florens' point of view, addressing the blacksmith. In writing her story, as opposed to his story (history), Florens is preserving her existence in a form of history. Feminist studies see writing and telling as an intimate act. Especially when what is being written is one's own life story. Lionnet (1995) postulates that autobiography helps women to go through the process of self-definition, and such an act of self-definition gives way to the narrative of self-discovery that authorises new subject. At a point where she comes to term with her life, Florens bleeds her telling through an act of remembering, inside a room she calls the 'talking room.' In pidgin English, Florens expresses her concern of what happens if the telling stops and also the fact that the blacksmith only learns from experience, not reading. But not long after that she thinks: 'Perhaps these words need the air that is out in the world. Need to fly up then fall, fall like ash over acres of primrose and mallow. Over a turquoise lake, beyond the eternal hemlocks, through clouds cut by rainbow and flavor the soil of the earth' (Morrison: 188). It is at this point we can see that what Florens is trying to leave behind is more than history, it is a legacy.

In the narrative portion of Florens' mother in the last chapter, we are provided with her impression on what it feels like being a female in a place where men can barge in at night and rape her. In Barbados, she faces her destiny to be displayed and bought by a plantation owner, a Portuguese Senhor

'I was burning sweat in cane only a short time when they took me away to sit on a platform in the sun. It was there I learned how I was not a person from my own country, nor from my families. I was negrita. Everything. Language, dress, gods, dance, habits, decoration, song-all of it cooked together in the color of my skin. So it was as a black that I was purchased by Senhor, taken out of the cane and shipped north to his tobacco plants. A hope, then' (Morrison: 194).

She learns how she is no longer seen as herself, an individual of flesh and blood coming from a family in Africa. To the eyes of the slave traders, she is a 'negrita,' whose existence is determined only by the colour of her skin. In the end, unlike minhamãe, as a slave descendant, Florens declares herself free: ' $\mathrm{I}$ am become wilderness but I am also Florens. In full.Unforgiven.Unforgiving. No ruth, my love. None. Hear me? Slave. Free. I last' (Morrison: 189). She perseveres, admitting that she has become 'wilderness' and also Florens; untamed, yet she embraces who she is. The last chapter in the novel can 
be taken as a critical view in pinpointing the dividing mark between the repressor and the represssed. There is nothing human about human trading regardless who is the actor behind the deed. And it becomes asad fact when we learn that the black Africans sold their own kind as slaves.

\section{CONCLUSION}

Critiques towards fate and circumstance, the characters' reaction in a situation, ways to compromise with the situation, and ways to comprehend one's identity can be posed in discussing these issues under the frame of postcolonial studies. The novel provides glimpses of slavery in colonial America and can infuse empathetic perspectives in discussing the issue of the politics of identity and culture that fits within Indonesian context. The empathy can surface from the fact that Indonesia also experienced colonial history. The practice of slavery can be pictured as similar to the practice of forced labour during D utch colonial government in the Dutch East Indies. But even when slavery is presented as the main frame of the novel, the story also branches into the struggle of a young female slave in the process of placing and identifying herself in the era of human trading. Indonesians can also relate these critiques as individuals of postcolonial selves. To conclude, Indonesians can relate to the story from a variety of angles, since the issue raised in the novel is multifaceted. Their empathetic views when placing themselves as part of colonial history help to grasp the urgency of raising the issue of slavery at the peak of its phase in the history of slavery. Since the novel also asserts the idea of looking at the issue objectively, seeing things not as simple as black and white, it also helps guide the readers to rethink the way commodification of humans was practiced one of the darkest eras in American history. The learned lesson proposed is clear: 'to be given dominion over another is a hard thing; to wrest dominion over another is a wrong thing; to give dominion of yourself to another is a wicked thing' (Morrison: 195-6).

\section{REFERENCES}

Conrad, J. (1962). Heart of Darkness.The Noton Anthdogy of Engish Literature (Vdume2). M. H. Abrams, et al (Eds.). New York: W. W. Norton \& Co.

Crowder, C. (Summer 2010). Toni Morrison discusses racism and "A Mercy" during keynote speech. Chicago Tribume 20 Oct. 2010. Retrieved 3 March 2015 from http:/ / articles.chicago tribune.com/ 2010 -10-20/ entertainment/ chi-books-morris on-keynote_1_toni-morrison-racism-spe ech

Ferguson, N. (2009). TheAscent of Maney: A Finanial Histary of the Wold [D ocumentary DVD]. Britain: Channel 4.

Harris, A.E. (2010). Women, Work and Bondage in Toni Morrison's A Mercy. Fonum on Public Pdigy: A Jaumal of the OxfordRaundTable

Lionnet, F.(1995). Postcdonial Representations: Women, Literature, Identity. U.S.A .: Cornell University Press.

Morrison, T.(2009). A Mery. New York: Vintage International.

------.(2008a). Predicting the Past: Interview by Susanna Rustin. The Guardan Guardian News and Media, Ltd. 1 Nov. 2008. Retrieved 1 March 2015 from: http:/ / www.theguardian.com/ books/ 20 08/ nov/ 01/ toni-morrison

-.---.(2008b). Toni Morrison On Human Bondage And A Post-Racial Age: Interview by Michel Martin. Tell MeMare (National Public Radio news)26 Dec. 2008. Retrieved 3 March 2015 from: http:/ / www.npr.org/ templates/ story/ st ory.php?storyId $=98679703$

Spivak, G. C.(1993). Outside in the Teaching Madhine New York: Routledge.

Todorov, T.(1984). The Conquest of America: TheQuestion of theOther. Translated from the French by Richard Howard. New York: Harper and Row. 
ACKNOWLEDGMENTS

My deepest gratitude goes to all 15 participants of the Study in the U.S.

Institutes (SUSI) in Contemporary
American Literature at the University of Louisville, Kentucky, for their contributions in the discussion of the novel during the commencement of the program.

\section{NOTES:}

${ }^{11}$ From an interview with Michel Martin in 2008

on a radio show Tell MeMarefrom NPR

(National Public Radio) News, scripted on NPR

website, under the title "Toni Morrison On

Human Bondage And A Post-Racial Age."

2From an Interview by Susanna

Rustin,"Predicting the Paste on TheGuardan,

Saturday 1 November.

3From a keynote speech as reported by

Courtney Crowder in Chicago Tribune, O ctober

20, 2010, in a coverage entitled "Toni Morrison

discusses racism and "A Mercy" during keynote

speech."

4 Retrieved from

<http:/ / www.history.com/ topics/ black-history

/ slavery>

5Literally "my mother" in Portuguese.

${ }^{6}$ This term can be defined as a condition where one is made to experience a change of fate. 